\title{
Supply ranges of stone blocks used in masonry bridges and their construction period along the East Royal Road in the Khmer Empire, Cambodia
}

\author{
Etsuo Uchida ${ }^{{ }^{*}}\left(\mathbb{D}\right.$, Yuichiro Sakurai ${ }^{1}$, Rathborith Cheng $^{2}$, Ichita Shimoda ${ }^{3}$ and Yu Saito ${ }^{1}$
}

\begin{abstract}
During the Angkor period, there were five Royal Roads linking the capital city of Angkor with provincial principal cities. Seven Temples d'étape, six Fire Shrines, and 25 masonry bridges were constructed along the East Royal Road to Preah Khan of Kompong Svay. We conducted measurements of magnetic susceptibility and chemical composition of laterite blocks and magnetic susceptibility of sandstone blocks used for the construction of the bridges to determine the supply ranges of the stone blocks and the construction ages based on the results obtained in this study and previous studies of Temples d'étape and Fire Shrines. The results suggest that most of the sandstone blocks for the bridge balustrades were supplied from quarries in the southeastern foothills of Kulen Mountain, but that the bridges close to Preah Khan of Kompong Svay have sandstone balustrades supplied from nearby quarries. In contrast, cluster and principal component analyses and t-tests using data for chemical composition and magnetic susceptibility of laterite blocks revealed that there were five sources of supply. These results elucidated that the supply ranges of laterite blocks were narrower than those of the sandstone blocks. Judging from magnetic susceptibilities, supply ranges, shapes, orientations of bedding planes, and stacking methods of the stone blocks, it was concluded that the construction age of the bridges is highly likely to have been in the early Angkor Wat period.
\end{abstract}

Keywords: Khmer monuments, East Royal Road, Bridge, Laterite, Sandstone, Chemical composition, Magnetic susceptibility, Cluster analysis, Principal component analysis

\section{Introduction}

The Khmer monuments consist of Hindu or Buddhist temples widely distributed across Cambodia, Thailand, Laos, and Vietnam, constructed mainly from the 9th to the 13th centuries. Among them, the temples distributed in and around Siem Reap, Cambodia, are now called the Angkor monuments. The Angkor area was the center of the Khmer Empire and covers approximately $400 \mathrm{~km}^{2}$. Conservation and restoration of the Angkor monuments

\footnotetext{
*Correspondence: weuchida@waseda.jp

${ }^{1}$ Department of Resources and Environmental Engineering, Faculty of Science and Engineering, Waseda University, Tokyo 169-8555, Japan Full list of author information is available at the end of the article
}

have been conducted since 1907, especially by the École Française d'Extrême-Orient (EFEO).

The buildings of the Angkor monuments were constructed mainly with sandstone and laterite blocks. Bricks were also used in the relatively old monuments constructed in the 9th and 10th centuries. The sandstones used in the Angkor monuments have been studied by Saurin [1], Delvert [2], Fusey [3], Uchida et al. [4, 5], and Carò and Im [6], and the laterites by Uchida et al. [7].

There were five Royal Roads connecting the capital city of Angkor to provincial cities: Preah Khan of Kompong Svay (East Royal Road) and Sambor Prei Kuk (Southeast Royal Road) in Cambodia, Phimai (Northwest Royal Road) and Sdok Kok Thom (West Royal Road) in 
Thailand, and Wat Phu in Laos (Northeast Royal Road) (Fig. 1) [8]. Six Temples d'étape (from west to east, Prasat Banteay Ampil, Prasat Chrei, Prasat Trapeang Khnar, Prasat Pram, Prasat Supheap Tbong, and Prasat Trapeang Chambok), seven Fire Shrines (from west to east, Fire Shrine of Preah Khan, Fire Shrine of Ta Prohm, Prasat Kansaeng, Prasat Toap Chey, Prasat Ta En, Prasat Supheap Cheung, and Prasat Kuk), and 25 masonry bridges were constructed along the East Royal Road that connects with Preah Khan of Kompong Svay (Prasat Bakan), which is located approximately $95 \mathrm{~km}$ east of the Angkor area (Fig. 2). There were approximately 17 Fire Shrines built with laterite blocks but no Temples d'étape along the Northwest Royal Road $[9,10]$. No Temples d'étape nor Fire Shrines exist along the other Royal Roads. These facts suggest the importance of the East Royal Road [11] compared with the other Royal Roads. Because many of the constructions along the East Royal Road were built with sandstone and/or laterite blocks, this Royal Road is useful for understanding the supply ranges of the sandstone and laterite blocks. Uchida et al. [12] conducted magnetic susceptibility measurements using a portable magnetic susceptibility meter on sandstone blocks used for Temples d'étape and Fire Shrines along the East Royal Road, and reported on the supply ranges of sandstone blocks in the Angkor Wat period (the late 11th to middle 12th centuries) and the Bayon period (the late 12th to middle 13th centuries) when these buildings along the East Royal Road were constructed, respectively. Temples d'étape and Fire Shrines are located about every 14 to $15 \mathrm{~km}$ along the East Royal Road. Temples d'étape are of an Angkor Wat style consisting of a Central Sanctuary, two Libraries, two or three Gopuras, and an Enclosure wall of similar dimensions (32 to $33 \mathrm{~m}$ wide and 37 to $38 \mathrm{~m}$ long), and are only found along the East Royal Road. A Fire Shrine is also called Dharmaçāāā, Teap Chei, Maison du charité, Gîte d'étape, Guest House or Resthouse [9, 13-21]. Fire Shrines built with sandstone blocks consist of a single building 4 to $5 \mathrm{~m}$ wide and 14 to $15 \mathrm{~m}$ long. In this study, non-destructive magnetic susceptibility measurements and chemical composition analyses were carried out for laterite and sandstone blocks used in the construction of the bridges along the East Royal Road, to clarify their supply ranges.

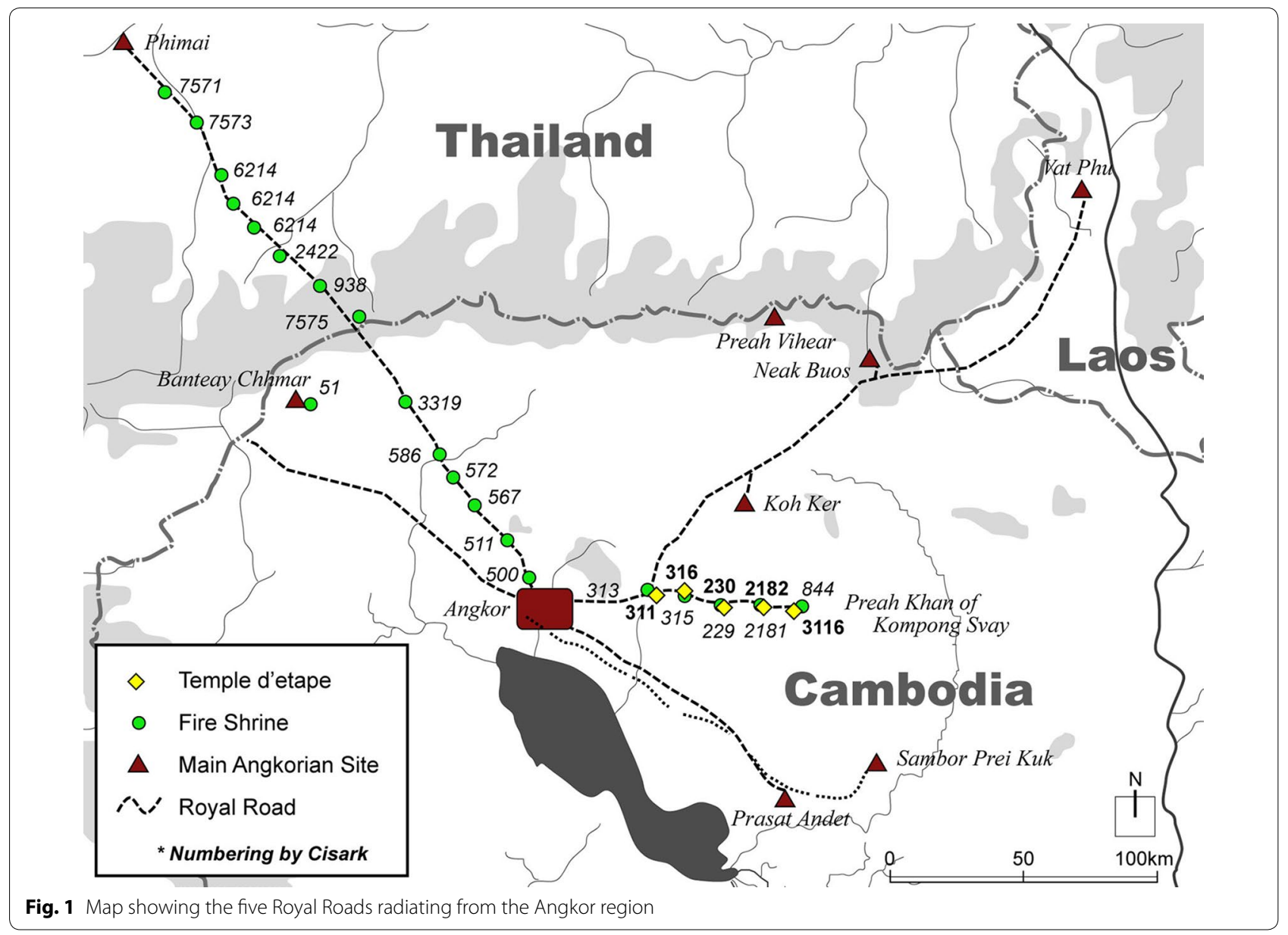




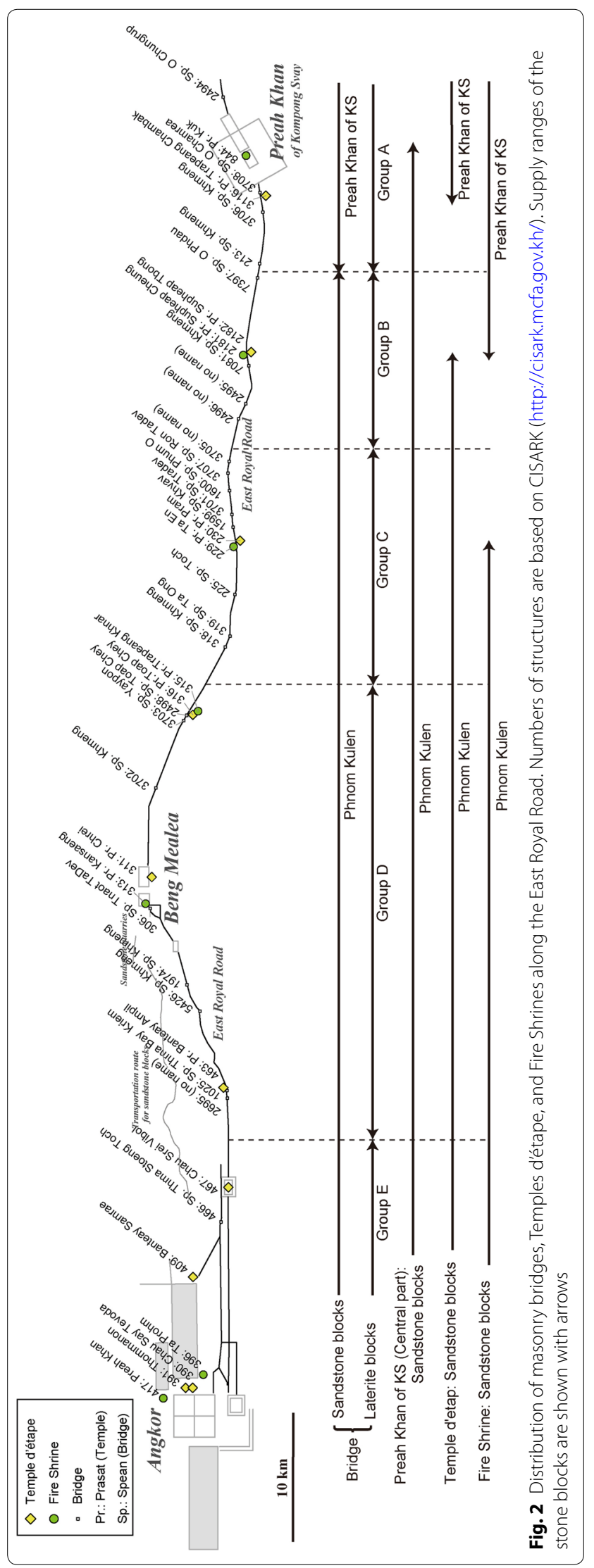


In addition, combining the results obtained in this study with those obtained previously by Uchida et al. [12] for the sandstone blocks in Temples d'étape and Fire Shrines, we investigate the construction age of the bridges along the East Royal Road.

There are 25 bridges built mainly of laterite blocks along the East Royal Road. Sandstone blocks were used for balustrades. The bridges have a corbel arch structure, in which laterite blocks are offset to meet at the apex of the archway. The sizes of the bridges vary, but many bridges are 10 to $30 \mathrm{~m}$ in length and 6 to $10 \mathrm{~m}$ in width. The largest bridge along the East Royal Road is Spean Ta Ong (no. 319, according to the Carte Interactive des Sites Archéologiques Khmers (CISARK; http://cisark.mcfa. gov.kh/), which was constructed over the Chikreng River at $65 \mathrm{~m}$ in length and $13 \mathrm{~m}$ in width (Fig. 3a). Several small bridges have no names, and several have the same name, "Spean Khmeng" (Fig. 2). According to Uchida et al. [7], two types of laterite can be distinguished in the Angkor monuments: porous laterite and pisolitic laterite. Both types of laterite consist mainly of the same minerals: goethite, hematite, kaolinite, and quartz. However, differences in the content of minor elements such as arsenic (As), antimony $(\mathrm{Sb})$, vanadium $(\mathrm{V})$, and strontium $(\mathrm{Sr})$ were found between them. Porous laterite is relatively rich in $\mathrm{Sr}$, As, and $\mathrm{Sb}$, but is depleted in $\mathrm{V}$. The laterite blocks used in the bridges in general show an intermediate texture between porous and pisolitic.

Sandstone blocks were used for the balustrades of the bridges, although many have been lost. Both ends of some balustrades were decorated with multi-headed Naga figures. The sandstone is gray to yellowish brown (feldspathic arenite) [4]. This sandstone occurs in the Red Terrain Formation (called the Phu Kradung Formation in
Thailand) of the Late Jurassic to Early Cretaceous [22], and was one of the most commonly used construction materials of the Angkor monuments. The sandstone was supplied from the southeastern foothills of Kulen Mountain, approximately $30 \mathrm{~km}$ northeast of the Angkor monuments [12]. Sandstone blocks were transported to the Angkor area using canals and rivers [12]. This is almost the shortest route from the quarry sites to the Angkor area, with a total distance of $34 \mathrm{~km}$.

\section{Previous studies}

\section{Bridge construction ages along the East Royal Road}

Judging from the decorative style of the sandstone balustrades, Boisselier [23] considered that all the bridges along the East Royal Road were built during the reigns of Suryavarman I (1002-1049 CE) and Suryavarman II (1113-ca.1150 CE), that is, in the Khleang period and the Angkor Wat period, respectively. Groslier [16] suggested that the Naga balustrades were added by Jayavarman VII (1182-ca.1218 CE), and the bridges themselves predated that, except for a few. Bruguier [24] suggested that previously existing wooden bridges were burned by the Cham in $1177 \mathrm{CE}$ and then rebuilt with stone blocks by Jayavarman VII. Based on a combination of node-networks, epigraphy, and architectural information, Hendrickson [8] inferred that the region along the East Royal Road was of great importance through the 12th century, and that the road system, including the bridges, was completed perhaps centuries before Jayavarman VII.

Decorations in various places, such as short pillars on the balustrades, are certainly similar to the Bayon style. In the Bayon period, it was common for Garuda to be engraved on the front of multi-headed Naga figures, but this composition is not found on the bridges along the

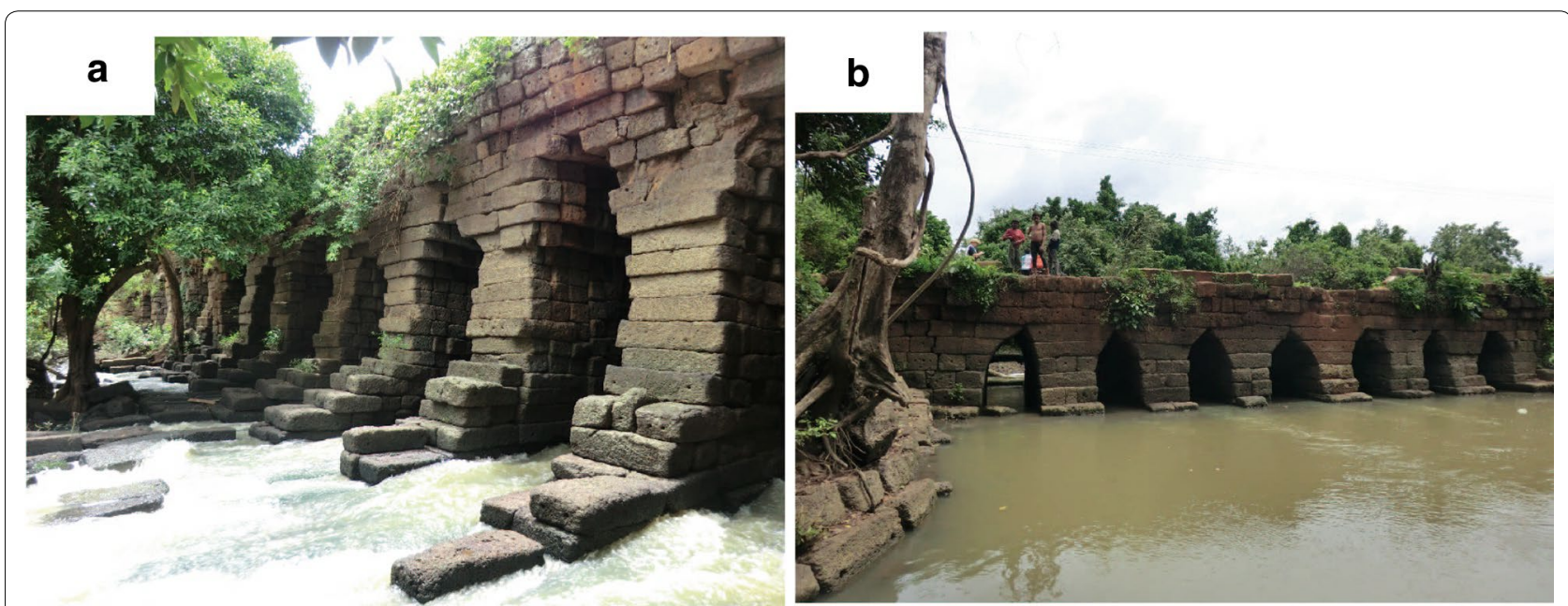

Fig. 3 Photographs of bridges along the East Royal Road. a Spean Ta Ong (no. 319) and b Spean Khvav (no. 1599) 
East Royal Road. Therefore, there is doubt in specifying this style. Furthermore, Buddha statues were engraved at the center of the hoods of multi-headed Naga, which are confirmed on bridge nos. 318, 319, and 1599 (CISARK; http://cisark.mcfa.gov.kh/). They are clearly due to modifications in the subsequent iconoclasm.

\section{Magnetic susceptibilities of sandstone blocks used in Temples d'étape, Fire Shrines and Preah Khan of Kompong Svay along the East Royal Road}

Magnetic susceptibility measurements of sandstone blocks used in the construction of Temples d'etape and Fire Shrines along the East Royal Road were carried out previously by Uchida et al. [25].

Preah Khan of Kompong Svay is located on the eastern end of the East Royal Road. Sandstone blocks with relatively high magnetic susceptibilities, ranging from 1.4 to $2.0 \times 10^{-3} \mathrm{SI}$ units, and some with low magnetic susceptibilities, ranging from 0.3 to $0.6 \times 10^{-3}$ SI units, were used in this temple complex. Sandstone blocks with high magnetic susceptibilities were used in Prasat Kat Kdei, which is the oldest temple in Preah Khan of Kompong Svay, constructed in the late Khleang period (the early 11th to middle 11th centuries) as suggested by the inscription K.161, and also in the buildings in the central part of Preah Khan of Kompong Svay such as the Central Sanctuary, Gopuras of the Inner Gallery, and the Northern and Southern Libraries. This finding suggests that sandstone blocks with high magnetic susceptibilities were used for construction in the early period, and then sandstone blocks with low magnetic susceptibilities began to be used later. Because the average magnetic susceptibility of sandstone blocks used in Prasat Kat Kdei is $1.60 \times 10^{-3}$ SI units, and the magnetic susceptibilities of sandstone blocks used in the Angkor monuments from the same period (the late Khleang period) range from 1.1 to $2.4 \times 10^{-3}$ SI units (Uchida et al. [5]), it is inferred that sandstone blocks with high magnetic susceptibilities in Preah Khan of Kompong Svay came from quarries in the southeastern foothills of Kulen Mountain. The buildings in the central area where the high magnetic susceptibility sandstone blocks were used are inferred to have been constructed in the Angkor Wat period because the cross section of the sandstone blocks is close to square in shape, the orientation of the bedding planes is almost horizontal, and the sandstone blocks were stacked with coursed ashlar [26, 27]. Because the magnetic susceptibilities of the sandstone blocks from the Angkor Wat period in the Angkor region were initially low and increased over time from 1.1 to $5.6 \times 10^{-3} \mathrm{SI}$ units [5], it is inferred that these buildings were constructed in the early Angkor Wat period (Fig. 2). Sandstone blocks with low magnetic susceptibilities ranging from 0.3 to $0.6 \times 10^{-3}$ SI units were not used in the Angkor monuments, and are not found in the ancient quarries in the southeastern foothills of Kulen Mountain [12]. Therefore, it is inferred that sandstone blocks with low magnetic susceptibilities were supplied from somewhere near Preah Khan of Kompong Svay. We confirmed that sandstone with similar low magnetic susceptibilities is distributed in the southern foothills ( $\left.13^{\circ} 38^{\prime} 24^{\prime \prime} \mathrm{N}, 105^{\circ} 01^{\prime} 11^{\prime \prime} \mathrm{E}\right)$ of Tbeng Mountain, approximately $30 \mathrm{~km}$ northeast of Preah Khan of Kompong Svay [25]. The average magnetic susceptibility of sandstone blocks measured in the modern sandstone quarry along the road on the east side of Tbeng Mountain was as low as $0.5 \times 10^{-3} \mathrm{SI}$ units. This value is concordant with the magnetic susceptibility of sandstone blocks in the later period of Preah Khan of Kompong Svay. Because sandstone blocks with high as well as low magnetic susceptibilities are found in the Inner and Outer Galleries, and because even the sandstone blocks from the Angkor Wat period with high magnetic susceptibilities have relatively low values, ranging from 1.2 to $2.0 \times 10^{-3} \mathrm{SI}$ units, it is presumed that the change from the sandstone quarry with high magnetic susceptibilities to that with low magnetic susceptibilities occurred in the early Angkor Wat period [5].

Along the East Royal Road, there are six Temples d'étape (from west to east, Prasat Banteay Ampil, Prasat Chrei, Prasat Toap Chey, Prasat Pram, Prasat Supheap Tbong, and Prasat Trapeang Chambok), which are thought to have been constructed in the Angkor Wat period [25]. The magnetic susceptibilities of the sandstone blocks in these buildings increased from west to east (from 2.84 to $4.48 \times 10^{-3}$ SI units) [25]. In contrast, the magnetic susceptibilities of sandstone blocks from Prasat Trapeang Chambok at the eastern end are low $\left(0.39 \times 10^{-3}\right.$ SI units), similar to those with low magnetic susceptibilities in Preah Khan of Kompong Svay. The change in magnetic susceptibilities of the sandstone blocks from Prasat Banteay Ampil to Prasat Supheap Tbong is similar to that in the magnetic susceptibilities of sandstone blocks in the early Angkor Wat period [5]. This finding suggests that Temples d'étape were constructed eastwards and that sandstone blocks were supplied from the southeastern foothills of Kulen Mountain (Fig. 8 in Uchida et al. [25]). In contrast, it is inferred that the sandstone blocks of Prasat Trapeang Chambok, at the eastern end, were supplied from a sandstone quarry near Preah Khan of Kompong Svay (Fig. 2).

Along the East Royal Road, there are seven Fire Shrines (from west to east, Fire Shrine of Ta Prohm, Fire Shrine of Preah Khan, Prasat Kansaeng, Prasat Trapeang Khnar, Prasat Ta En, Prasat Supheap Chueng, and Prasat Kuk) which are considered to have been constructed in the Bayon period [25]. The two westernmost Fire Shrines 
of Ta Prohm and Preah Khan are located in the Angkor region. Similar to the Temples d'étape, the magnetic susceptibilities of the sandstone blocks used for the Fire Shrines increased from west to east (Fig. 9 in Uchida et al. [25]). The magnetic susceptibilities of the sandstone blocks used in the Angkor monuments tend to increase gradually from 0.7 to $3.1 \times 10^{-3}$ SI units in and after the main Bayon period (the end of the 12th to early 13th centuries) [5]. It is inferred from this finding that, similar to the Temples d'etape, the Fire Shrines were also constructed from west to east, and the sandstone blocks used for construction were supplied from the southeastern foothills of Kulen Mountain. However, it is inferred that the Fire Shrines at Prasat Supheap Cheung $\left(0.36 \times 10^{-3}\right.$ SI units) and Prasat Kuk $\left(0.40 \times 10^{-3}\right.$ SI units $)$ are made of low magnetic susceptibility sandstone blocks supplied from a quarry near Preah Khan of Kompong Svay (Fig. 2).

As described previously, at the beginning of the Angkor Wat period sandstone blocks were transported from the southeastern foothills of Kulen Mountain to Preah Khan of Kompong Svay along the whole length of the East Royal Road, around $60 \mathrm{~km}$. In the early Angkor Wat period, sandstone blocks were supplied to Prasat Supheap Tbong from Kulen Mountain, but by the late Bayon period, they were only supplied as far as Prasat Ta En (Prasat Pram) (Fig. 2). This confirms that the supply ranges of sandstone blocks from Kulen Mountain became narrower over time.

\section{Methods}

In this study, non-destructive chemical composition analyses were carried out on laterite blocks used for bridge construction along the East Royal Road using a portable $\mathrm{X}$-ray fluorescence analyzer equipped with a silicon drift detector and a $4 \mathrm{~W}, 50 \mathrm{kV}$ Rh X-ray tube configuration (Type DP-4000-C, Innov-X Systems Delta Premium, Waltham, MA, USA). The measurements were carried out in a soil mode for precise analysis of minor heavy elements (using three different beams, beam 1 : $40 \mathrm{kV}, 100 \mu \mathrm{A}$, beam 2: $40 \mathrm{kV}, 100 \mu \mathrm{A}$, beam 3: $15 \mathrm{kV}$, $200 \mu \mathrm{A})$. Measurement time was $20 \mathrm{~s}$ for each beam, and total measurement time was fixed at $60 \mathrm{~s}$. Before measurement, the instrument was calibrated using 10 reference rocks from the Geological Survey of Japan (JA-1, JA-2, JB-1b, JB-2, JB-3, JG-1a, JG-2, JGb-1, JR-1, and JR-2) [28]. Analytical precisions were summarized in Table 1. The measurements were made on flat and non-deteriorated surfaces of stone blocks not covered with algae or lichens. The measuring surfaces were cleaned with a brush. For each bridge, measurements were made on flat surfaces of 10 different laterite blocks selected randomly, and the median values were obtained.
In addition, we measured non-destructively magnetic susceptibilities of laterite blocks of the bridges and sandstone blocks of the balustrades using a portable magnetic susceptibility meter (ZH instruments SM 30, Brno, Czech Republic) with a reading surface of $5 \mathrm{~cm} \times 5 \mathrm{~cm}$. Measurements were made on randomly selected 40 flat and non-deteriorated laterite block surfaces in total for each bridge. Although most of the sandstone blocks have disappeared, possibly due to reuse by local people, measurements were made on up to 20 sandstone blocks selected randomly for each bridge. For four bridges, nos. 2498, 3701, 1600, and 3705 (CISARK; http://cisark.mcfa. gov.kh/), no sandstone blocks remained, so we could not measure magnetic susceptibilities. Magnetic susceptibility measurements were performed on flat surfaces not deteriorated physically and/or chemically, and also not covered with algae or lichens, and the median values were obtained. The magnetic susceptibilities of sandstone depend on the content of magnetite $\left(\mathrm{Fe}_{3} \mathrm{O}_{4}\right)$, which is a minor mineral in the sandstone. Because magnetite is a heavy mineral compared with major rock-forming minerals such as quartz, feldspar and micas, it concentrates in specific place. In addition, the content of magnetite in sandstone depend on source rocks. These factors determine the horizontal and vertical difference in magnetic susceptibility of sandstone layer. Conversely, the magnetic susceptibilities of laterite are due to large amounts of goethite $(\mathrm{FeO}(\mathrm{OH}))$ and hematite $\left(\mathrm{Fe}_{2} \mathrm{O}_{3}\right)$, as well as minor amounts of maghemite $\left(\mathrm{Fe}_{2} \mathrm{O}_{3}\right)$. Maghemite is a highly magnetic mineral, like magnetite [29].

Thicknesses were measured for 25 laterite blocks of each bridge and the median values were obtained. The thicknesses of both sandstone and laterite blocks decreased over time in the Angkor monuments, from around $45 \mathrm{~cm}$ before the Angkor Wat period, to around $25 \mathrm{~cm}$ in the late Bayon period. The cross section of stone blocks was square until the Bapuon period, but changed to rectangular after that [30]. We can see stone blocks with both square and rectangular cross sections in the Angkor Wat period. In addition, the orientation of bedding planes was random before the Baphuon period, but almost horizontal in the Angkor Wat period and later [4].

To compare with laterite blocks used for bridge construction, laterite blocks used in temples at Chau Say Tevoda, Prasat Suor Prat, Thommanon, Angkor Wat, and Banteay Samre constructed in the Angkor Wat period, and also Ta Prohm, Angkor Thom, and Banteay Kdei constructed in the Bayon period, were subjected to chemical composition analyses, magnetic susceptibility measurements, and thickness measurements. According to Uchida et al. [7], there were no clear differences in chemical compositions or magnetic susceptibilities between the laterite blocks used for the buildings 


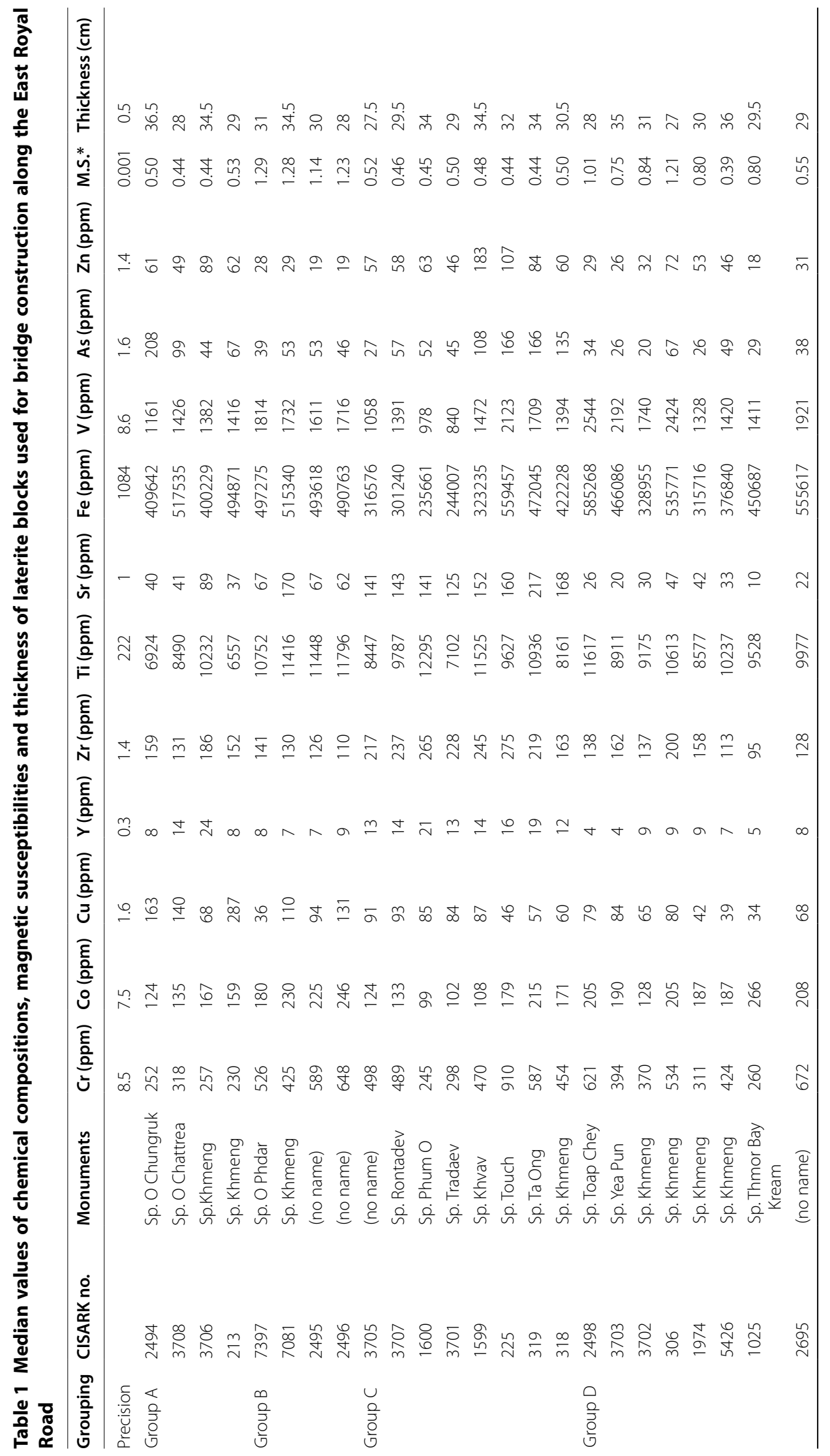




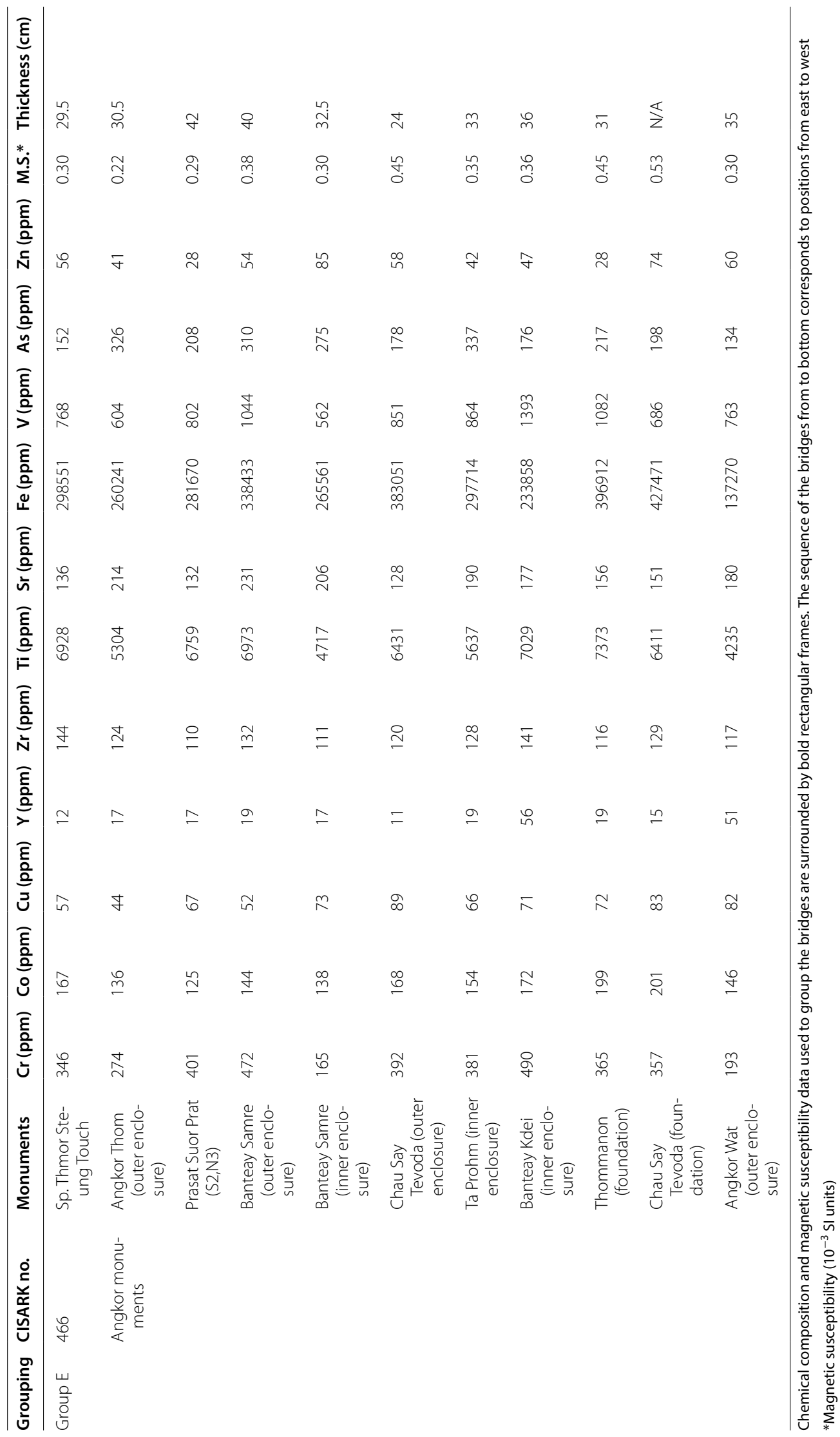


constructed in the Angkor Wat period and those built in the Bayon period in the Angkor monuments. This finding suggests the strong possibility that they were supplied from the same quarrying area. However, their source is still unknown.

To infer the supply range of laterite blocks used for the bridges, hierarchical cluster and principal component analyses were conducted. The median concentrations of each element and magnetic susceptibility (Table 1) standardised to a constant total were used in the cluster and principal component analyses (Additional file 1) [31-33]. T-tests were performed to examine the confidence of the deduced groupings of the bridges using chemical compositions and magnetic susceptibility of laterite and sandstone blocks. R (ver. 3.5.3) was used for the cluster and principal component analyses and t-tests [34].

\section{Results}

\section{Chemical composition}

The major components of laterite used in the Angkor monuments were $\mathrm{Fe}_{2} \mathrm{O}_{3}, \mathrm{Al}_{2} \mathrm{O}_{3}$, and $\mathrm{SiO}_{2}$ [7]. The portable X-ray fluorescence analysis in soil mode revealed 16 elements across all laterite blocks: $\mathrm{K}, \mathrm{Cr}, \mathrm{Co}, \mathrm{Cu}, \mathrm{Zn}$, As, Y, Zr, Ti, Sr, P, S, Ca, Mn, Fe, and V. Silicon (Si) and aluminum $(\mathrm{Al})$ were not detectable by the portable X-ray fluorescence analyzer in soil mode. Five elements (K, P, S, $\mathrm{Ca}$, and $\mathrm{Mn}$ ) that exhibited large variations or no systematic variations were excluded; then, the bridges were classified into at least five groups based on contents of the other 11 elements (Table 1 and Additional file 2), Group A to Group E, from east to west (Figs. 2 and 4). The laterite blocks of Group A are relatively depleted in $\mathrm{Cr}$, Co, $\mathrm{Ti}, \mathrm{Sr}$, and $\mathrm{V}$, but are enriched in $\mathrm{Cu}, \mathrm{Y}$, and $\mathrm{Zn}$ compared with those of Group B. The laterite blocks of Group B are depleted in $\mathrm{Y}, \mathrm{Zr}$, Sr, and $\mathrm{Zn}$, but are enriched in Co and $\mathrm{V}$ compared with those of Group C. The laterite blocks of Group C are enriched in Y, Sr, and As compared with those of Group D. The laterite blocks of Group D are depleted in $\mathrm{Y}, \mathrm{Sr}$, and As compared with those of Group E. These facts suggest that the laterite blocks were supplied from five different quarrying areas. Only the laterite blocks used for bridge no. 466 (CISARK; http://cisar k.mcfa.gov.kh/) in Group E, near the western end of the East Royal Road closest to the Angkor monuments, are similar in chemical composition to the laterite blocks used for the Angkor monuments from the Angkor Wat period to the Bayon period. It is possible that these blocks came from the same quarrying area.

In the Angkor monuments, gray to yellowish brown sandstone was used as a main construction material, but there is no difference in the chemical composition between the temples. Our preliminary surveys have also revealed that the gray to yellowish brown sandstone used in the temples along the East Royal Road is not different from the sandstone in the Angkor monuments in terms of chemical composition. In this study, therefore, the chemical composition analysis of sandstone used in the bridges of the East Royal Road was not conducted.

\section{Magnetic susceptibility}

The median magnetic susceptibilities of the laterite blocks in the bridges range from 0.30 to $1.29 \times 10^{-3} \mathrm{SI}$ units (Table 1, Fig. 4, and Additional file 3). The same groupings as those based on the chemical compositions were obtained: the median magnetic susceptibilities of the laterite blocks of Group A are low, ranging from 0.44 to $0.53 \times 10^{-3}$ SI units; those of Group B are high, ranging from 1.14 to $1.29 \times 10^{-3}$ SI units; those of Group C are low, ranging from 0.44 to $0.52 \times 10^{-3}$ SI units; those of Group D range from 0.39 to $1.21 \times 10^{-3}$ SI units; and the median magnetic susceptibility of the laterite blocks of Group E is as low as $0.30 \times 10^{-3} \mathrm{SI}$ units (Table 1 and Fig. 4). The magnetic susceptibilities of laterite blocks in Group E, closest to the Angkor monuments, are in the same range as those of the laterite blocks in the Angkor monuments from the Angkor Wat period to the Bayon period ( 0.22 to $0.53 \times 10^{-3} \mathrm{SI}$ units), and it is inferred that they were supplied from the same quarrying area.

The median magnetic susceptibilities of the sandstone blocks used for the bridge balustrades range from 0.23 to $3.43 \times 10^{-3}$ SI units (Fig. 5 and Additional file 4). The number of sandstone blocks is small and they are widely dispersed. No sandstone blocks remained for bridges nos. 2498, 3701, 1600 and 3705 (CISARK; http://cisar k.mcfa.gov.kh/). Sandstone blocks of the four bridges nos. 213, 3706, 3708, and 2494 near Preah Khan of Kompong Svay on the eastern side of the East Royal Road have low median magnetic susceptibilities, ranging from 0.23 to $0.51 \times 10^{-3}$ SI units, averaging $0.31 \times 10^{-3}$ SI units. Sandstone blocks of the bridges on the western side have higher median magnetic susceptibilities, ranging from 0.75 to $3.41 \times 10^{-3}$ SI units, averaging $1.73 \times 10^{-3} \mathrm{SI}$ units.

\section{Thickness of laterite blocks}

The laterite blocks used in construction of the bridges have rectangular ends, not square ends, and their median thickness ranges from 27.5 to $36.5 \mathrm{~cm}$ (Table 1 and Additional file 5). These results are almost concordant with those obtained by Uchida and Ando [30] for the laterite and sandstone blocks used for temples in the Angkor monuments from the Angkor Wat period to the Bayon period, not before the Angkor Wat period. 

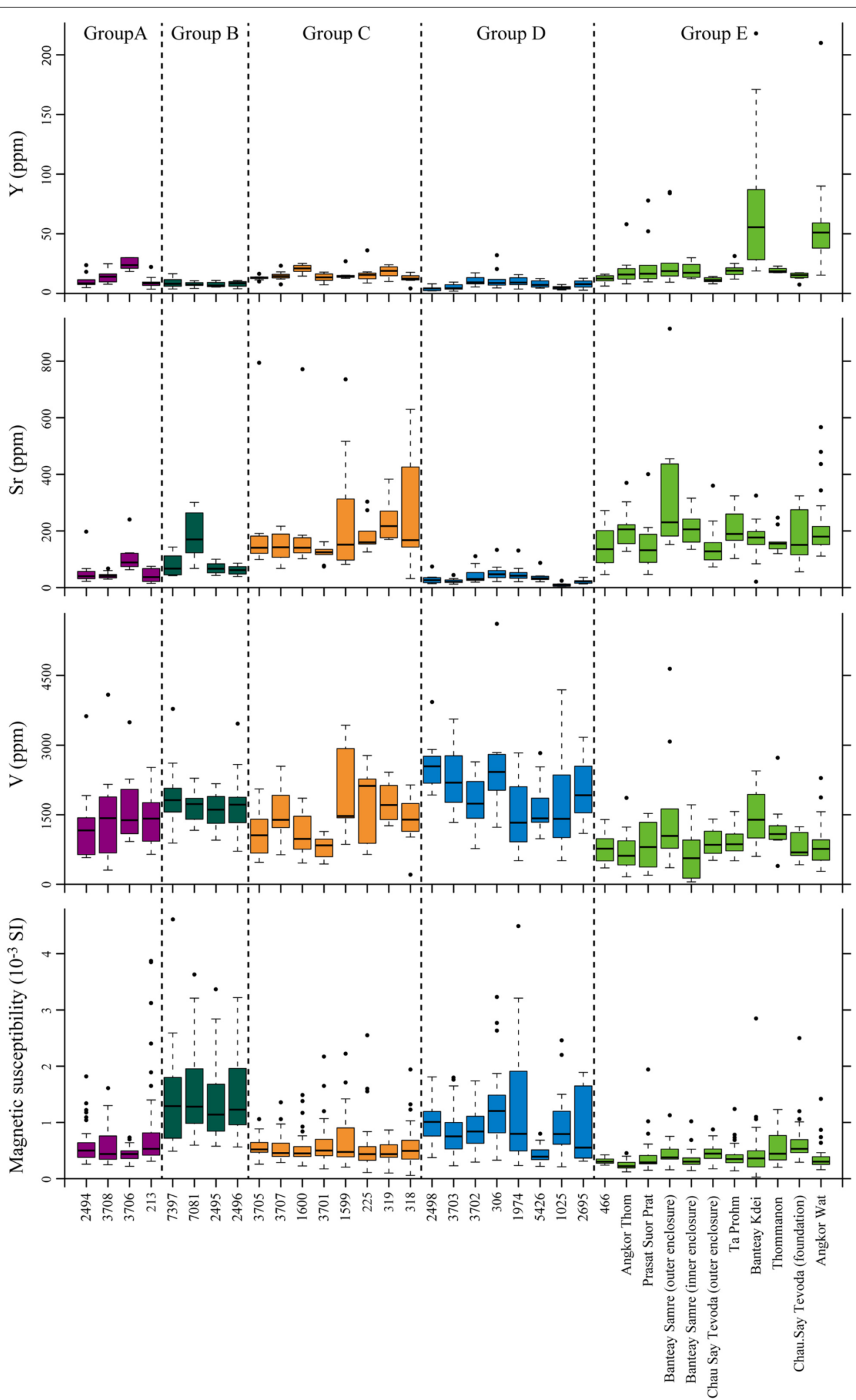

Fig. 4 Box and whisker diagrams for contents of Y, Sr and V, and magnetic susceptibility of laterite blocks used in the bridges along the East Royal Road. Five groups (Group A to Group E) can be distinguished 


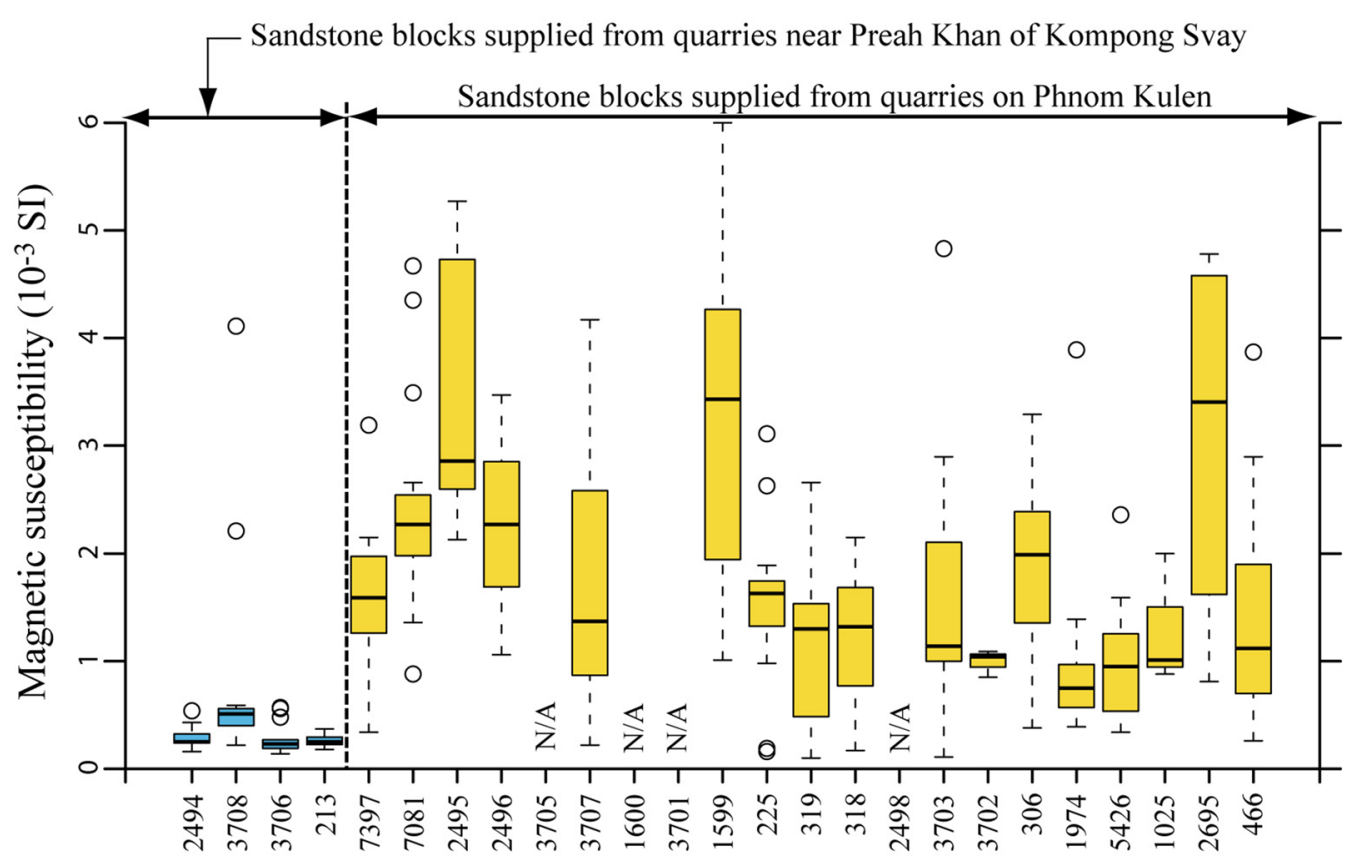

Fig. 5 Box and whisker diagram for magnetic susceptibilities of sandstone blocks used for the bridges along the East Royal Road

\section{Hierarchical cluster analysis of laterite blocks}

We performed hierarchical cluster analyses using single linkage, complete linkage, group average, centroid, median, and Ward's methods (Additional file 6), but the analysis result by Ward's method with a squared Euclidean distance gave the result most consistent with the hypothesis presented in this paper compared to other methods. In other words, Ward's method classified the laterites used in the Angkor Wat to Bayon periods into one group (Fig. 6), while the other methods split them into at least two groups. Ward's method gave almost the same groupings (Group A to Group E) as those obtained from the chemical composition and magnetic susceptibility data shown in Table 1 and Fig. 4. However, bridge no. 318 (CISARK; http://cisark.mcfa.gov.kh/) was reclassified from Group C (Table 1) to Group E in the cluster analysis, and bridge no. 3706 was reclassified from Group A to Group C.

\section{Principal component analysis of laterite blocks}

Results of the principal component analysis are shown in Fig. 7 as principal components 1 vs. 2 and principal components 1 vs. 3 diagrams. In the former, the area of Group A classified in Table 1 and Fig. 4 slightly overlaps with the area of Group $C$, but in the latter, the area of Group A does not overlap with the area of Group $C$ at all. In both diagrams, the area of Group B is completely included in the area of Group D. In both diagrams, the area of Group A is separated completely from the area of Group B, the area of Group B from the area of Group C, the area of Group $C$ from the area of Group D, and the area of Group D from the area of Group E. The laterite blocks of Group A are enriched in $\mathrm{Cu}$; those of Group B and $\mathrm{D}$ are enriched in $\mathrm{Co}, \mathrm{V}$, and $\mathrm{Fe}$ and have higher magnetic susceptibilities; those of Group $C$ are enriched in $\mathrm{Zn}$ and $\mathrm{Zr}$; and those of Group E are enriched in Sr, As, and Y. These facts suggest that the laterite blocks of each group (Group A to Group E) were supplied from different quarrying areas.

Bridge no. 3706 (CISARK; http://cisark.mcfa.gov.kh/) was classified as both Group A and Group $C$ in the principal components 1 vs. 2 diagram, but was classified as Group A, not Group C, in the principal components 1 vs. 3 diagram. Bridge no. 318 was classified as both Group $A$ and Group $C$ in the principal components 1 vs. 2 diagram, but was classified as Group $C$ in the principal components 1 vs. 3 diagram. These results are concordant with the results obtained by grouping based on chemical composition and magnetic susceptibility data in Table 1 and Fig. 4.

Studies on laterite blocks in the Angkor monuments [7] revealed that Fe, $\mathrm{V}$ and magnetic susceptibility have a positive correlation to each other, and that $\mathrm{Sr}, \mathrm{Y}$ and $\mathrm{As}$ also have a positive correlation. It is, however, clarified 


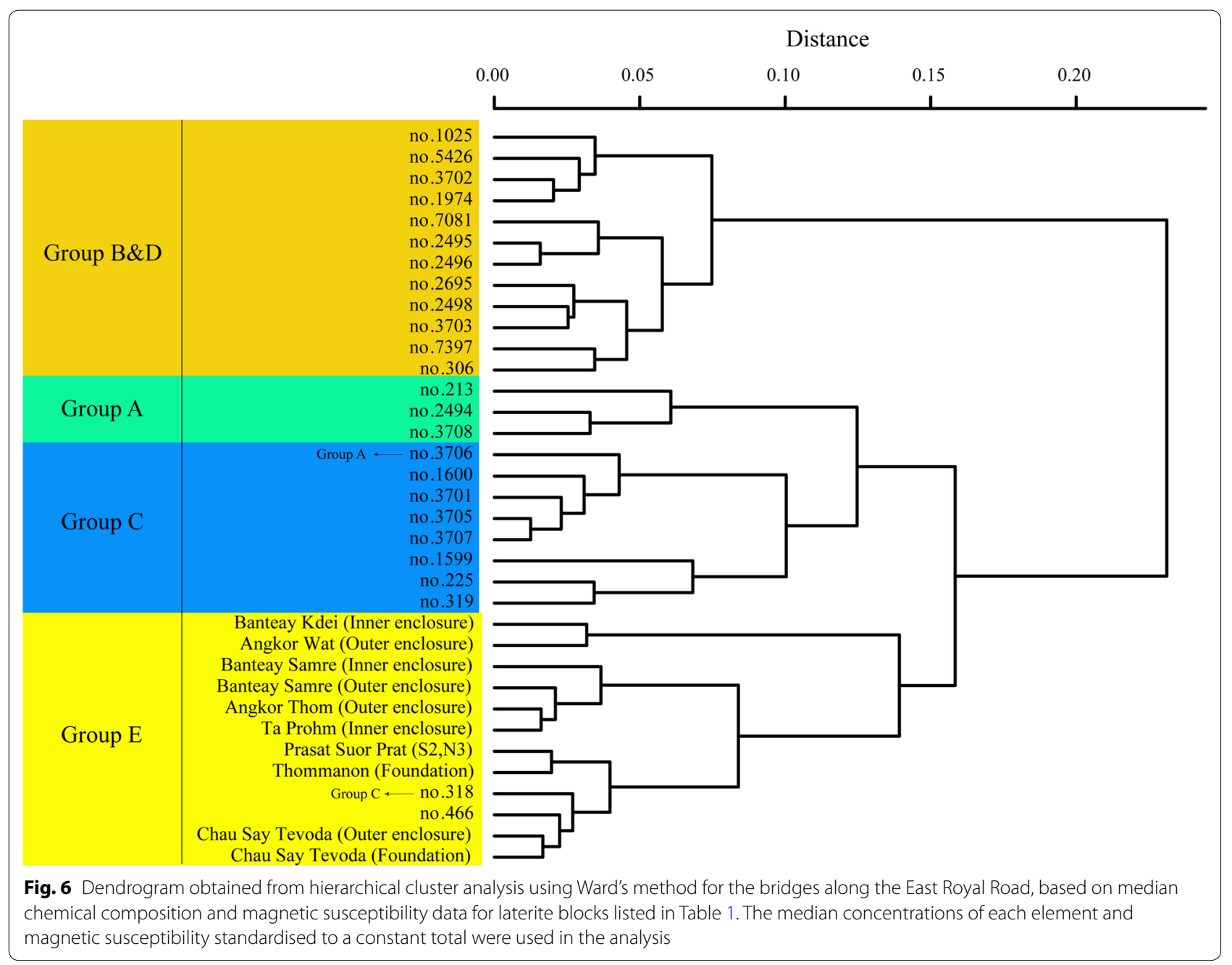

that there is a negative correlation between the former and the latter. These results are in a good agreement with those of the principal component analysis.

\section{T-tests to examine the confidence of the grouping of the bridges}

We conducted t-tests to examine the confidence of the groupings of the bridges based on magnetic susceptibility of laterite and sandstone blocks (Additional files 2 and 3 ), and $p$ values were calculated. As a result, $p$ values for magnetic susceptibility of laterite blocks between Group A and Group B, Group B and Group C, Group C and Group D, and Group D and Group E, were all extremely low (less than $2.65 \times 10^{-18}$ ) (Table 2). These results revealed that laterite blocks of Group A and Group B, Group B and Group C, Group C and Group D, and Group D and Group E were supplied from different quarrying areas, respectively. In addition, $\mathrm{p}$ value for magnetic susceptibility between the sandstone blocks used in the bridges 2494 to 213 and those in the bridges 7397 to 466 was extremely small $\left(4.45 \times 10^{-28}\right)$. This result suggests a clear difference in provenance.

The t-tests were also conducted to examine the confidence of the grouping of the bridges based on $\mathrm{Y}, \mathrm{V}$, and Sr contents of laterite (Additional file 1). As a result, $p$ values were less than 0.05 with one exception ( $p$ value for V: 0.136 between Group A and Group B) (Table 2). These results clearly support that laterite blocks of Group A and Group B, Group B and Group C, Group C and Group D, and Group D and Group E were supplied from different quarrying areas, respectively.

\section{Discussion}

Based on the results for magnetic susceptibilities of sandstone blocks and those for chemical compositions, magnetic susceptibilities and thicknesses of laterite blocks, presented in the previous chapter, we discuss here the stone block supply range and construction period for the bridges along the East Royal Road. 


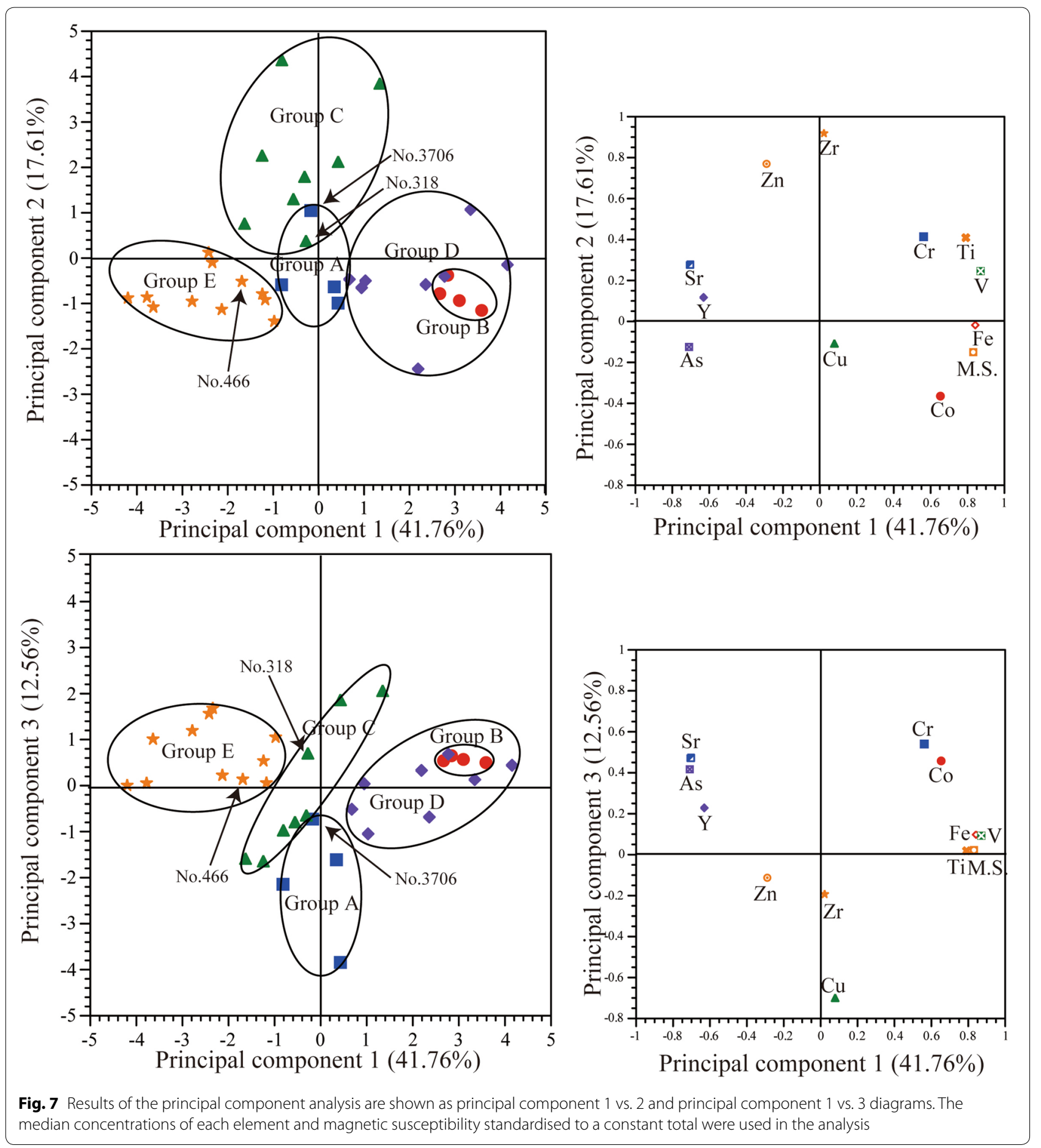

\section{Sandstone blocks}

The same tendency as Temples d'étape and Fire Shrines is observed for the magnetic susceptibilities of sandstone blocks used in the balustrades of the bridges along the East Royal Road; that is, median magnetic susceptibilities on the west side are high $\left(0.75\right.$ to $3.41 \times 10^{-3} \mathrm{SI}$ units), whereas the four bridges on the east side (nos. 213, 3706, 3708, and 2494; CISARK; http://cisark.mcfa. gov.kh/) have low median magnetic susceptibilities ( 0.23 to $0.51 \times 10^{-3} \mathrm{SI}$ units). This finding suggests that the sandstone blocks for the bridges on the western side were supplied from Kulen Mountain, but that those for 
Table 2 P values obtained by t-tests to examine the confidence of the grouping of the bridges along the East Royal Road based on magnetic susceptibility and chemical compositions of laterite blocks

\begin{tabular}{lllll}
\hline & Groups A and B & Groups B and C & Groups C and D & Groups D and E \\
\hline Magnetic susceptibility & $3.06 \times 10^{-25}$ & $4.05 \times 10^{-33}$ & $2.65 \times 10^{-18}$ & $1.52 \times 10^{-34}$ \\
Y content & $4.61 \times 10^{-6}$ & $7.11 \times 10^{-20}$ & $1.55 \times 10^{-19}$ & $3.76 \times 10^{-12}$ \\
Sr content & $6.96 \times 10^{-4}$ & $2.10 \times 10^{-6}$ & $2.14 \times 10^{-15}$ & $8.04 \times 10^{-33}$ \\
V content & 0.136 & 0.0151 & $5.29 \times 10^{-6}$ & $2.26 \times 10^{-16}$ \\
\hline
\end{tabular}

the bridges on the eastern side were supplied from the quarry near Preah Khan of Kompong Svay (Fig. 2). The boundary between high and low magnetic susceptibility sandstone blocks is consistent with the boundary for sandstone blocks used for Temples d'étape, but is different from the boundary for sandstone blocks used for Fire Shrines. Judging from the supply ranges of the sandstone blocks used for the balustrades of the bridges, it is inferred that the bridges were constructed from the early Angkor Wat period to the early Bayon period. Regarding the magnetic susceptibilities of sandstone blocks used for the balustrades of the bridges, if we assume construction occurred in the early Angkor Wat period, contradictions do not arise with magnetic susceptibilities of sandstone blocks used in the Angkor monuments. Judging from these facts, it is highly likely that the balustrades of the bridges along the East Royal Road were constructed in the early Angkor Wat period.

\section{Laterite blocks}

Based on chemical compositions and magnetic susceptibilities of laterite blocks, the bridges were classified into five groups (Group A to Group E) (Table 1 and Fig. 4). Sr, $\mathrm{V}$, and $\mathrm{Y}$ contents, and magnetic susceptibilities are good indicators for grouping the laterite bridges (Tables 1 and 2). Analysis revealed that only bridge no. 466 (CISARK; http://cisark.mcfa.gov.kh/), classified as Group E, was constructed from the same laterite blocks as those used from the Angkor Wat period to the Bayon period. This finding indicates that the laterite blocks used in the construction of the Angkor monuments were supplied from the area west of bridge no. 2695. The supply ranges of the laterite blocks used for the construction of the other laterite bridges are also narrower than those of the sandstone blocks. This result suggests that laterite occurs in many areas along the East Royal Road, and that procurement of laterite blocks was easier than that of sandstone blocks.

Sandstone blocks were supplied from the southeastern foothills of Kulen Mountain to Preah Khan of Kompong Svay in the beginning of the Angkor Wat period, and were transported approximately $60 \mathrm{~km}$. Because canals have not been confirmed in the area between Kulen
Mountain and Preah Khan of Kompong Svay, stone blocks may have been transported over land. Transportation of stone blocks by canal would have been difficult because the altitude is the highest in the area around bridge no. 7081 (about $90 \mathrm{~m}$ above sea level), between Kulen Mountain (about $80 \mathrm{~m}$ above sea level in Beng Mealea) and Preah Khan of Kompong Svay (about $65 \mathrm{~m}$ above sea level). The lowest altitude is near bridge no. 319 (around $40 \mathrm{~m}$ above sea level). This represents a difference in elevation of around $50 \mathrm{~m}$. As mentioned above, it is inferred that sandstone blocks were transported from Kulen Mountain to Preah Khan of Kompong Svay in the beginning of the Angkor Wat period, so it is reasonable to infer that the East Royal Road, as well as the masonry bridges, were already constructed at the time. The facts that the boundary between Group A and Group B for the laterite bridges coincides with the supply boundary of the sandstone blocks used for the balustrades, and that it also coincides with the supply boundary of the sandstone blocks used in Temple d'etapes, support the idea that the bridges along the East Royal Road were constructed in the early Angkor period. In addition, the facts that rectangular cross section laterite blocks instead of square ones were used for the bridge construction, that they were stacked with coursed ashlar, and that the orientation of bedding planes is almost horizontal, suggest that the bridges were constructed in the early Angkor Wat period, not before the Angkor Wat period [27].

\section{Conclusions}

Sandstone and laterite blocks used in the 25 bridges along the East Royal Road connecting the capital city of Angkor to Preah Khan of Kompong Svay were investigated to clarify the supply range of stone blocks and the construction period of the bridges.

There are marked geographical differences in magnetic susceptibilities of sandstone blocks used for the balustrades of the bridges along the East Royal Road. Based on these magnetic susceptibilities, it was inferred that sandstone blocks in the bridges east of bridge no. 213 (CISARK; http://cisark.mcfa.gov.kh/) were supplied from a sandstone quarry near Preah Khan of Kompong Svay, and that those west of bridge no. 7397 
were supplied from the southeastern foothills of Kulen Mountain. This result is concordant with that obtained from the sandstone blocks used for the Temple d'étapes along the East Royal Road [25].

The laterite blocks, which were the main bridge construction materials, are presumed to have been supplied from five different quarrying areas, and the supply ranges were much narrower than those of the sandstone blocks. This finding indicates that laterite is widely distributed along the East Royal Road, and that the procurement of laterite blocks was easier than that of sandstone blocks. However, these ancient laterite quarries have not yet been found.

Judging from the median magnetic susceptibilities, supply ranges, and characteristics of laterite blocks, such as cross sectional shapes and the orientations of bedding planes, the construction of the masonry bridges along the East Royal Road is highly likely to have occurred in the early Angkor Wat period (the late 11 th to early 12 th centuries).

\section{Supplementary information}

Supplementary information accompanies this paper at https://doi. org/10.1186/s40494-020-00383-2.

Additional file 1: Data used for the cluster and principal component analyses. The median concentrations of each element and magnetic susceptibility data listed in Table 1 were standardised to a constant total.

Additional file 2: Raw data of chemical composition analysis of laterite blocks used for the bridge construction along the East Royal Road by a portable XRF.

Additional file 3: Raw data of magnetic susceptibilities of laterite blocks used for the bridge construction along the East Royal Road.

Additional file 4: Raw data of magnetic susceptibilities of sandstone blocks used for the bridge construction along the East Royal Road.

Additional file 5: Raw data of thickness of laterite blocks used for the bridge construction along the East Royal Road.

Additional file 6: Results of cluster analyses using single linkage, complete linkage, group average, centroid, median, and Ward's methods.

\section{Abbreviations}

EFEO: École Française d'Extrême-Orient; CISARK: Carte Interactive des Sites Archéologiques Khmers.

\section{Acknowledgements}

This research was conducted with the permission of the Authority for Protection and Management of Angkor and the Region of Siem Reap (APSARA. National Authority), Cambodia. We express our thanks to the members of the Japanese Government Team for Safeguarding Angkor for their help during our research in Cambodia. The authors are grateful to two anonymous reviewers for their insightful reviews and valuable comments to improve the quality of the manuscript.

\section{Authors' contributions}

EU conceived and coordinated this research. EU, YSak, RC and IS conducted the field investigation. EU and YSai performed multivariate analyses, EU carried out the interpretation of the results, and drafted the manuscript. EU, YSai and IS made all figures and table. All authors read and approved the final manuscript.

\section{Funding}

This research was financially supported in part by Grants-in-Aid for Scientific Research of the Japan Society for the Promotion of Science (Uchida: no. 23401001) and Waseda University Grants for Special Research Projects (Uchida: no. 2016B-137).

\section{Availability of data and materials}

Not applicable.

\section{Competing interests}

The authors declare that they have no competing interests.

\section{Author details}

${ }^{1}$ Department of Resources and Environmental Engineering, Faculty of Science and Engineering, Waseda University, Tokyo 169-8555, Japan. ${ }^{2}$ Department of Geology, Ministry of Mines and Energy, Phnom Penh 12210, Cambodia. ${ }^{3}$ World Heritage Studies, Graduate School of Comprehensive Human Sciences, University of Tsukuba, Ibaraki 305-0821, Japan.

Received: 19 January 2020 Accepted: 10 April 2020

Published online: 16 April 2020

\section{References}

1. Saurin E. Quelques remarques sur le grès d'Angkor. Bulletin de l'École Française d'Extrême-Orient. 1954;46:619-34.

2. Delvert J. Recherches sur l'erosion des grès des monuments d'Angkor. Bulletin de l'École Française d'Extrême-Orient. 1963;51:453-534.

3. Fusey P. Altération biologiques des grès Cambodgiens et recherche de moyens de protection. Paris: École Française d'Extrême-Orient; 1991. p. 99.

4. Uchida E, Ogawa Y, Nakagawa T. The stone materials of the Angkor monuments, Cambodia. The magnetic susceptibility and the orientation of the bedding plane of the sandstone. J Mineral Petrol Econ Geol. 1998;93:411-26.

5. Uchida E, Cunin C, Suda C, Ueno A, Nakagawa T. Consideration on the construction process and the sandstone quarries during Angkor period based on the magnetic susceptibility. J Archaeol Sci. 2007;34:924-35.

6. Carò F, Im S. Khmer sandstone quarries of Kulen Mountain and Koh Ker: a petrographic and geochemical study. J Archaeological Sci. 2012:39:1455-66.

7. Uchida E, Maeda N, Nakagawa T. The laterites of the Angkor monuments, Cambodia. The grouping of the monuments on the basis of the laterites. J Petrol Mineral Econ Geol. 1999;94:162-75.

8. Hendrickson M. Historic routes to Angkor: development of the Khmer road system (ninth to thirteenth centuries AD) in mainland Southeast Asia. Antiquity. 2010;84:480-96.

9. Finot L. Dharmaçâlâs au Cambodge. BEFEO XXV, 1925; p. 417-422.

10. Im S, Surat L. The living Angkor Road project: connectivity within Ancient Mainland Southeast Asia. N Lett Center Southeast Asian Studies Kyoto University. 2015;71:4-8.

11. Hendrickson M, Evans D. Reimaging the city of fire and iron: a landscape archaeology of the Angkor period industrial complex of Preah Khan of Kompong Svay, Cambodia (ca 9th to 13th centuries A.D.). Field Archaeol. 2015;40:644-64.

12. Uchida E, Shimoda I. Quarries and transportation routes of Angkor monument sandstone blocks. J Archaeol Sci. 2013;40:1158-64.

13. de Lajonquière LE. Inventaire descriptif des monuments du Cambodge, vol. 4. Paris: E Leroux; 1902. p. 432.

14. Foucher A. Nouvelles et Melanges. Critique de E. Lunet de Lajonquiére, 1902, Inventaire descriptive des monuments du Cambodge. J Asiatique. 1903(10):174-80

15. Briggs LP. The ancient Khmer empire. Philadelphia: The American Philosophical Society; 1951. p. 295.

16. Groslier BP. Inscriptions du Bayon. In: Dumarçay J, Groslier BP, editors. Le Bayon: Histoire architecturale du temple. Paris: Mémoires archéologiques de l'EFEO 3. 1973; p. 83-306.

17. Chandler D. A history of Cambodia. Boulder: Westview Press; 1983. p. 237.

18. Higham C. The archaeology of Mainland Southeast Asia. Cambridge: Cambridge University Press; 1989. 
19. Welch DJ. Archaeology of Northeast Thailand in relation to the pre-Khmer and Khmer historical record. Int J Historical Archaeol. 1998;2:205-33.

20. Dagens B. Les Khmers. Paris: Guide Belles Lettres des Civilisations. Les Belles Lettres; 2003.

21. Stark MT. Pre-Angkorean and Ankorean Cambodia. In: Bellwood P, Glover I, editors. A cultural history of Southeast Asia: from earliest times to the Indic civilizations. New York: Routledge Gurzon Press; 2004. p. 89-119.

22. Meesook A. Cretaceous. In: Ridd MF, Barber AJ, Crow MJ, editors. The geology of Thailand. London: Geological Society; 2011. p. 169-84.

23. Boisselier J. Asie de Sud-Est: I. Le Cambodge. Pairs, Picard, Manuel d'archéologie d'Extrême-Orient, vol 1, 1966; pp. 479.

24. Bruguier B. Les ponds en pierre du Cambodge ancient: aménagement ou contrôle du territoire. Bulletin de l'Ecole Française d'Extrême-Orient. 2000;87:529-51.

25. Uchida E, Shimoda I, Shimoda M. Consideration of the construction period of the Khmer temples along the East Royal road to Preah Khan of Kompong Svay and the provenance of sandstone blocks based on their magnetic susceptibility. Archaeol Discov. 2013;1:37-48.

26. Jacques C, Lafond P. L'Empire Khmer: Cités et Sanctuaires Vème-XIllème siècle. Paris: Fayard: 2004. p. 398

27. Uchida E, Suda C, Ueno A, Shimoda I, Nakagawa T. Estimation of the construction period of Prasat Suor Prat in the Angkor monuments, Cambodia, based on the characteristics of its stone materials and the radioactive carbon age of charcoal fragments. J Archaeol Sci. 2005;32:1339-45.
28. Imai N, Terashima S, Itoh S, Ando A. 1994 compilation values for GSJ reference samples, "Igneous rock series". Geochem J. 1995;29:91-5.

29. Gains RV, Skinner HCW, Foord EE, Mason B, Rosenzweig A. Dana's New Mineralogy. 8th ed. New York: Wiley; 1997. p. 1819.

30. Uchida E, Ando D. Petrological Survey 2000. In Annual Report on the Technical Survey of Angkor Monument 2001, Japanese Government Team for Safeguarding Angkor. 2001; p. 225-247.

31. Swan ARH, Sandilands M. Introduction to geological data analysis. London: Blackwell Science; 1995. p. 446.

32. Funahashi T. Basics of multivariate analysis II (Principal Component Analysis): theory and exercise using R. Amazon Service International, Inc. 2015; pp. 58.

33. Jolliffe IT. Principal Component analysis. 2nd ed. New York: Springer; 2002 p. 487.

34. R Core Team. R: a language and environment for statistical computing. $\mathrm{R}$ Foundation for Statistical Computing, Vienna; 2019.

\section{Publisher's Note}

Springer Nature remains neutral with regard to jurisdictional claims in published maps and institutional affiliations.

\section{Submit your manuscript to a SpringerOpen ${ }^{\circ}$ journal and benefit from:}

- Convenient online submission

- Rigorous peer review

- Open access: articles freely available online

- High visibility within the field

- Retaining the copyright to your article

Submit your next manuscript at springeropen.com 